\title{
Seasonality in the transmission of schistosomiasis and in populations of its snail intermediate hosts in and around a sugar irrigation scheme at Richard Toll, Senegal
}

\author{
R. F. STURROCK ${ }^{1}$, O.-T. DIAW ${ }^{2}$, I. TALLA ${ }^{3}$, M. NIANG ${ }^{3}$, J.-P. PIAU ${ }^{3}$ and A. CAPRON \\ ${ }^{1}$ Department of Infectious and Tropical Diseases, London School of Hygiene E Tropical Medicine, Keppel Street, \\ London WC1E $7 H T$, UK \\ ${ }^{2}$ Service de Parasitologie, (L.N.E.R.V.), Institut Sénégalais de Réserches Agricoles, BP 2057, Dakar, Sénégal \\ ${ }^{3}$ Programme ESPOIR, District Médicale de Richard Toll, BP 394, Richard Toll, Sénégal \\ ${ }^{4}$ Institut Pasteur de Lille, 1 Rue du Professor Calmette, 59000 Lille CEDEX, France
}

SUMMARY

Irrigation for intensive sugar cultivation started in the early 1980s at Richard Toll, some $100 \mathrm{~km}$ from the mouth of the Senegal River. Infections with Schistosoma mansoni were first seen in late 1988. This study records quantitative snail surveys for over 3 years from 1992 at sites representing different habitats in and around the irrigation scheme. Populations of both Biomphalaria pfeifferi (the intermediate host of S. mansoni) and Bulinus spp. (mainly B. truncatus, the local host of $S$. bovis) peaked in late 'spring' or early 'summer', depending on the habitat, and then remained low until the following 'spring'. B. pfeifferi favoured smaller, man-made habitats with most transmission between May and August each year. The less abundant Bulinus spp. favoured larger natural and man-made habitats with most $S$. bovis transmission between April and July. S. mansoni infections were more, but $S$. bovis infections were less abundant than other trematodes in their respective snail hosts. Ecological changes in the early 1980s due to sugar irrigation pre-dated similar, more widespread changes in the late 1980s when the completion of dams across the Senegal River prevented seasonal rain fed floods and sea water intrusion. S. mansoni has since spread rapidly around Richard Toll. The incompatibility of the local $S$. haematobium strains with the dominant bulinid snails has so far prevented an epidemic of urinary schistosomiasis at Richard Toll, but the invasion of similar downstream habitats by susceptible B. globosus is worrying. The principal control measure, chemotherapy, given in the 'winter' would minimise the rate of reinfection. It could be reinforced by judicious mollusciciding within the sugar irrigation scheme but not elsewhere.

Key words: Schistosomiasis, S. mansoni, S. haematobium, S. bovis, Biomphalaria pfeifferi, Bulinus spp., population biology, transmission, temperature, seasonality.

\section{INTRODUCTION}

Human surveys along the middle and lower reaches of the Senegal River Basin reported isolated Schistosoma haematobium foci but no S. mansoni in the 1970 s and early 1980s (Jobin, Negron-Aponte \& Michelson, 1976; Monjour et al. 1981; Chaine \& Malek, 1983; Vercruysse, Southgate \& Rollinson, 1985; Malek \& Chaine, 1989). Bulinus spp. transmitted S. haematobium focally throughout the region and animal schistosomes-predominantly S. bovis and, possibly, S. curassoni (Rollinson et al. 1990; Vercruysse et al. 1994). Only two small, isolated colonies of Biomphalaria pfeifferi were detected (Chaine \& Malek, 1983). S. mansoni was first reported at Richard Toll in 1988 (Talla et al. 1990). As diagnostic facilities improved, the number of cases increased rapidly to epidemic proportions (Talla, Kongs \& Verlé, 1992). The epidemic had been preceded by significant agricultural changes in the region and the construction of the Manantali Dam, upstream in Mali, and the Diama Dam near the mouth of the Senegal River.

Traditional agriculture along the middle and lower reaches of the river had relied on seasonal floods (Diop et al. 1994), similar to basin irrigation in Egypt (Abdel-Waheb, 1982). Silt-laden flood water from seasonal rains upstream reached the area between July and September each year, giving high water levels with fast flows. Water levels dropped as the flood passed and, when the flow eventually stopped, sea water intruded more than $100 \mathrm{~km}$ from the river mouth causing the saline soil conditions and water unsuitable for irrigating many crops.

Large-scale irrigation was introduced for commercial sugar cultivation at Richard Toll in the early 1980s. Fresh flood water was diverted through the newly constructed Canal Taouey to the natural Lac de Guiers, south of Richard Toll, and released later to irrigate some 10000 hectares of sugar cane. Completion of the lower dam prevented sea water intrusion after 1985, making water available throughout the year to irrigate salt-sensitive crops outside the sugar scheme. Water in the upper dam finally reached spillway level in 1991, severely altering the annual flood cycle, rendering ineffective traditional irrigation and creating a need for modern irrigation schemes, especially for rice (Diop et al. 1994). 
These agricultural and hydrological changes were accompanied by major agro-industrial developments at Richard Toll. Massive immigration increased the population at least five-fold to $\sim 50000$ by 1990 with no parallel infrastructure improvement, particularly of sanitation, water supplies and housing (Handschumacher et al. 1992, 1994). An influx of refugees from Mauritania in 1989/1990 aggravated the situation. The net result of all these factors was a substantial change in the ecology of the lower Senegal River Valley favouring S. mansoni transmission around Richard Toll. Control has so far relied entirely on praziquantel treatment variously for symptomatic cases, for seasonal sugar workers leaving the region, and for systematic treatment in some districts of the town and its environs (Talla et al. 1992; Gryseels et al. 1994; Stelma et al. 1995; Picquet et al. 1996, 1998; Ernould, Ba \& Sellin, 1999a).

Diaw et al. $(1990,1991)$ reported large B. pfeifferi populations with high $S$. mansoni infection rates in a cross-sectional survey of different habitats around Richard Toll. Belot, Geerts \& Diouf (1993) reported much lower infection rates from an incomplete, oneyear longitudinal survey of irrigation canal sites outside the town boundaries in 1989/90 and concluded that transmission was continuous with little evidence of seasonality. Deme (1993), continuing surveys in similar sites in 1991/92, found rather more seasonal variation.

This paper reports the findings of fortnightly snail surveys of a variety of habitats from May 1992 to July 1995 at sites selected mostly for extensive human water contact. The object was to detect any seasonality of S. mansoni transmission by B. pfeifferi, with simultaneous observations on Bulinus spp., mainly B. truncatus (Syn. B. truncatus rohlfsiBrown, 1994).

\section{MATERIALS AND METHODS}

\section{Study area}

Richard Toll $\left(16 \cdot 38^{\circ} \mathrm{N} ; 15 \cdot 78^{\circ} \mathrm{W}\right.$; alt. $\left.<10 \mathrm{~m}\right)$ lies on the southern bank of the Senegal River $100 \mathrm{~km}$ east of its mouth on the Atlantic Ocean (Talla et al. 1990; Handschumacher et al. 1994). Briefly, the town is T-shaped with 7 main districts linked by two minor districts to the village of Ndombo to the south. The Senegal River forms the northern boundary across the T. The new, man-made Canal Taouey cuts south through the natural, meandering Marigot Taouey down the stem of the T, from the river to the Lac de Guiers.

Open canals and drains from the sugar irrigation scheme run through or beside most districts and provide the only reliable source of domestic water for many people. Water is siphoned into some house- holds, but many people continue to collect it by hand and to have direct contact with sites on the margins of natural and man-made water bodies in and around the town for washing clothes, personal washing, bathing, swimming, recreation, fishing, and washing cars and domestic animals. Many houses have some rudimentary sanitation (Handschumacher et al. 1994) but there is abundant evidence of promiscuous defaecation at almost every water contact site. Women of all ages openly use these sites despite a strong Mohammedan influence.

\section{Climate}

Senegal lies in the Sahel Zone but the cold Canary Current cools its coast. Winds off the Sahara cause extensive dust and sand storms between April and June. There is a limited rainy season between July and September when thunderstorms give localised but unreliable rainfall. Relative humidity is low for the most of the year. Mean air temperatures at Richard Toll are several degrees higher than at the coast, ranging from $<20^{\circ} \mathrm{C}$ in January to $>40{ }^{\circ} \mathrm{C}$ in September, with a diurnal range of $5-20^{\circ} \mathrm{C}$ depending on the cloud or dust cover.

\section{Sugar irrigation}

Water was lifted by pumps at the northern end of the Canal Taouey into two open, elevated main canals to two irrigation areas: one area to the east of the town, the other to the west and extending south to the northern shore of the Lac de Guiers. The sugar refinery draws water from the western main canal, the outfall of which is used for rice irrigation beyond the sugar scheme boundary. Water is fed by gravity from the main canals to a network of secondary and tertiary canals whence it is siphoned through plastic pipes into furrows in the individual fields. Excess water is led by porous, sub-surface pipes to deep, open main drains to be pumped either into the river or the Lac de Guiers, or back into the main canals if its salinity is low enough. Concrete junction boxes control water distribution throughout the irrigation network. The earth-lined canals and drains have to be cleared regularly (by hand, mechanically or with herbicides) to prevent aquatic and intrusive marginal vegetation impeding water flows.

The larger canals flow continuously except in the rare periods of heavy rainfall but minor canals are filled only as needed in each 12-14 day irrigation cycle, and surface water remains on the fields for only one or two days. (Excess water persists longer to leach out unwanted salts during reclamation of saline land.) Fields are cultivated and replanted on a three year cycle. Different sugar cane cultivars, ripening at different rates, are grown in blocks in each field to provide a continuous supply of cane for the refinery 
except in the rainy season when it closes for maintenance. Consequently, secondary canals are rarely dry for more than 10-12 days and residual pools in the junction boxes provide refuges for snails between irrigation cycles.

\section{Selection of snail sampling sites and sampling procedures}

Snail sites were chosen mostly for easy access within the town on the basis of evidence of extensive human water contact and the presence of snails, including infected snails, during pilot surveys. Some remote sites, less subject to human interference, were also included to represent the conditions within the sugar fields. Six sites were included at Ndombo to give transmission information for a separate study (Gryseels et al. 1994). Sampling began in May 1992 at 24 sites ( 2 river, 3 Marigot, 5 Canal Taouey, 6 main canal, 7 secondary canal and 1 drain). Eight more were added in 1994 (2 Canal Taouey, 5 Marigot and 1 secondary canal).

At each site, a marked length of the bank about $25 \mathrm{~m}$ long was searched for $10 \mathrm{~min}$ by two technicians using snail scoops (Olivier \& Schneiderman, 1956; Ouma et al. 1989). B. pfeifferi and Bulinus spp. were placed in labelled plastic containers. Prevailing site conditions were noted and sub-surface water temperature measured at the end of each search. (N.B. At Ndombo the searches were extended to $20 \mathrm{~min}$ to increase snail recoveries).

Sites were sampled fortnightly between $07 \cdot 00$ and 10.00 h: $1-8$ on day $1,9-16$ on day $2,17-24$ on day 3 and 25-32 on day 4 . Snails were taken to a field laboratory, washed in clean water and exposed individually in glass tubes in about $10 \mathrm{ml}$ of filtered water. A $30-40 \mathrm{~min}$ outdoor exposure to indirect sunlight preceded exposure to a low wattage electric lamp in an air-conditioned laboratory. Cercariae were detected by eye and their identity confirmed using a low power dissecting microscope. Snails were kept overnight for a final examination and then destroyed.

Cercariae were classified as either schistosome (furcocercous) cercariae or cercariae of other trematodes. Several isolates of furcocercous cercariae from $B$. pfeifferi were passaged through mice to confirm the identification as S. mansoni (Sène, 1994; Fallon et al. 1995). This process failed with furcocercous cercariae from Bulinus spp. which were assumed to have been predominantly $S$. bovis as most were from $B$. truncatus: the few $(<1 \%)$ from the rarely collected B. forskalii and B. globosus may have been $S$. bovis or $S$. haematobium respectively (Vercruysse et al. 1985; Diaw et al. 1990; Rollinson et al. 1990). Amphistome cercariae and xiphidocercariae were also shed by both $B$. pfeifferi and Bulinus spp. but it was not possible to identify them further.

\section{Data handling and analysis}

After each collection, data from individual site field forms were entered onto computer spreadsheets for analysis using standard statistical packages. Snail counts were transformed to $\log _{10}(x+1)$ and percentages to angles for the full data from 85 collections at 24 sites. Because the data were unbalanced with respect to the number of samples per habitat, only one-way analysis of variance with available statistics packages was possible, giving an excessive number of degrees of freedom (df) for the error term. To explore interactions between the two main factors (habitat and collection time) by two-way analysis of variance, the full data were simplified into a balanced summary table (Sturrock et al. 1994; Fulford et al. 1996). The original data sets were divided into two subsets comprising alternate collections (time samples) with the collection numbers coded by the month in which they were made. A summary table was then derived comprising 144 replicated observations $(2 \times 12$ months $\times 6$ habitats $)$. Because both analyses gave essentially the same results (with one exception - see below), for main factor effects, only analyses of the summary data are reported in the text, and habitat $\times$ time interactions only where they were significant at $P<0 \cdot 05$.

Mean monthly schistosome-to-total trematode infection ratios were calculated from the summary data (Sturrock et al. 1994). The generally piecemeal chemotherapy campaigns during this study were unlikely to have affected these ratios at Richard Toll so they will form a base-line for any changes due to future, systematic campaigns.

Monthly transmission potential indices (MTPI) were also derived from the summary tables (Klumpp, 1982). The mean number of infected snails collected per site in a month was expressed as a proportion of annual mean totals to give a general picture of transmission within a calendar year. For analysis, the logit transformation was used to normalise the data, adding or subtracting respectively 0.000001 from extreme values of 0 and 1 to bring them within the permitted limits of $>0$ to $<1$. (N.B. The sum of 12 untransformed monthly proportions equals 1 for each habitat but the sum of the transformed monthly proportions does not. Habitats with continuous, low infection rates score less than those with intermittent, but high, infection rates.)

\section{RESULTS}

Table 1 summarises the full data from the 85 fortnightly collections as means by habitat. Also shown are the results of one-way analyses of variance on the full data for differences between habitats. Fig. 1 illustrates the fortnightly collection means for temperature and for both B. pfeifferi and Bulinus 
Table 1. Geometric means (GM) by habitat of water temperatures and recoveries of $B$. pfeifferi and Bulinus spp.: total and infected with schistosomes or other trematodes

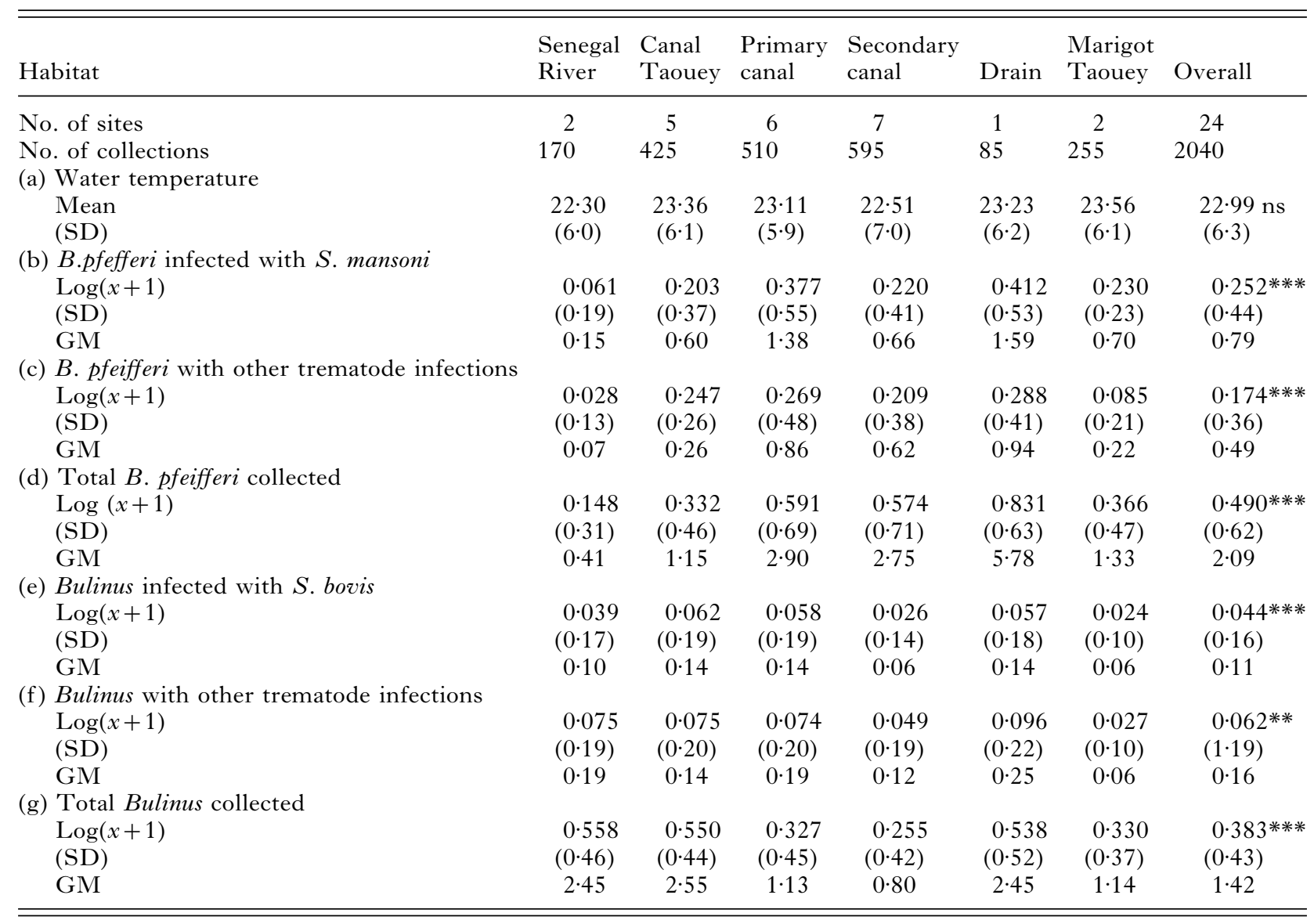

$\log (x+1)=$ mean of raw counts $(x)$ transformed to $\log _{10}(x+1)$.

$(\mathrm{SD})=$ Standard deviation.

ns, **, ***: $P$ for one-way analysis of variance of habitat means $>0 \cdot 05,0 \cdot 01$ and $<0.001$ respectively.

spp. and their respective trematode infections. Years 1, 2 and 3 start in May 1992, 1993 and 1994, respectively. For descriptive purposes, it is convenient to use 'seasons' normally associated with northern latitudes when discussing these results, even though Richard Toll lies within the tropics.

\section{Water temperature}

Mean water temperatures (Table 1(a)) for the full data from the first 76 surveys of the initial 24 sites (no measurements were possible for the last 9 collections) did not differ by habitat from analysis of the full data $\left(\mathrm{F}_{5,1776 \mathrm{df}}=1.7, P>0.05\right)$. In contrast, using the summary data suggested that the river and the secondary canals were significantly cooler than the rest $\left(\mathrm{F}_{5,72 \mathrm{df}}=6 \cdot 2 ; P<0 \cdot 001\right)$. However, this habitat difference may be an artifact due to bias in the measurement of water temperatures: river sites were always sampled early in the morning, before they were warmed by the sun, and many secondary canals were dry in the heat of the summer.

Water temperature (Fig. 1A) showed a clear seasonal variation peaking in the summer/autumn 'flood' season (August to November), when the river was full of warm water from inland, and were minimal in mid-winter and early spring (January to April). There was a significant difference by month $\left(\mathrm{F}_{11,72}=247 \cdot 6 ; P<0 \cdot 001\right)$.

Basic B. pfeifferi results

Total snails. Overall geometric mean (GM) B. pfeifferi recoveries varied considerably by habitat (Table $1(\mathrm{~d})$ ): primary canals, secondary canals and the drain yielded substantially more snails than the Canal Taouey and Marigot, and the river yielded even less $\left(\mathrm{F}_{5,72}=84 \cdot 0 ; P<0 \cdot 001\right)$. GM recoveries also showed clear seasonal variations (Fig. 1C). Peak numbers varied between years with summer populations (May to August) always greater than the rest $\left(\mathrm{F}_{11,72}=28.8 ; \quad P<0.001\right)$ after rapid population growth in spring and early summer, followed by a decline when high mid-summer temperatures set in. Minimal populations persisted through the winter before the cycle was repeated. A significant month $x$ habitat interaction (data not shown) was due mainly to river populations peaking rather earlier than the rest and disappearing through much of the winter $\left(\mathrm{F}_{55,72}=2 \cdot 8 ; P<0.001\right)$. 


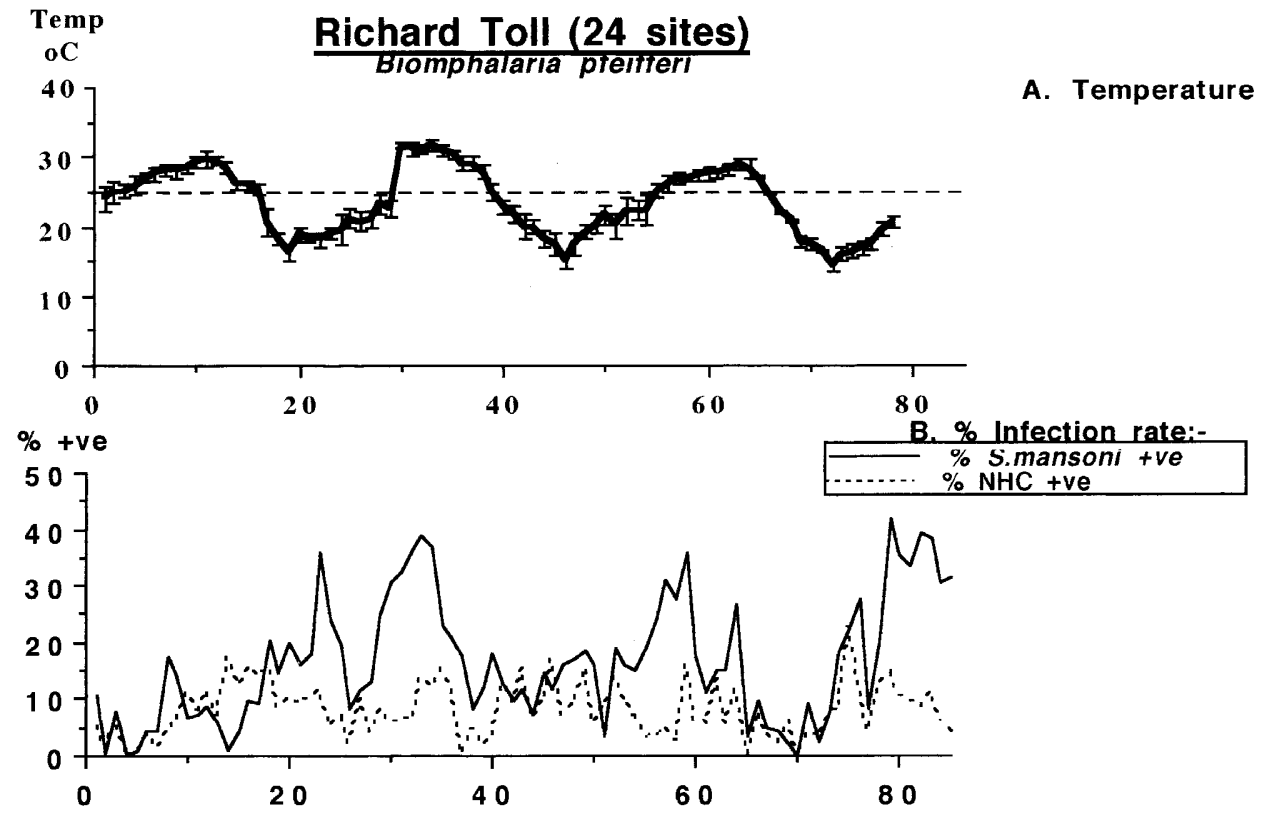

$(G M)$
$(16.00)$
$(10.00)$
$(8.00)$
$(5.00)$
$(3.00)$
$(2.00)$
$(1.00)$
$(0.50)$
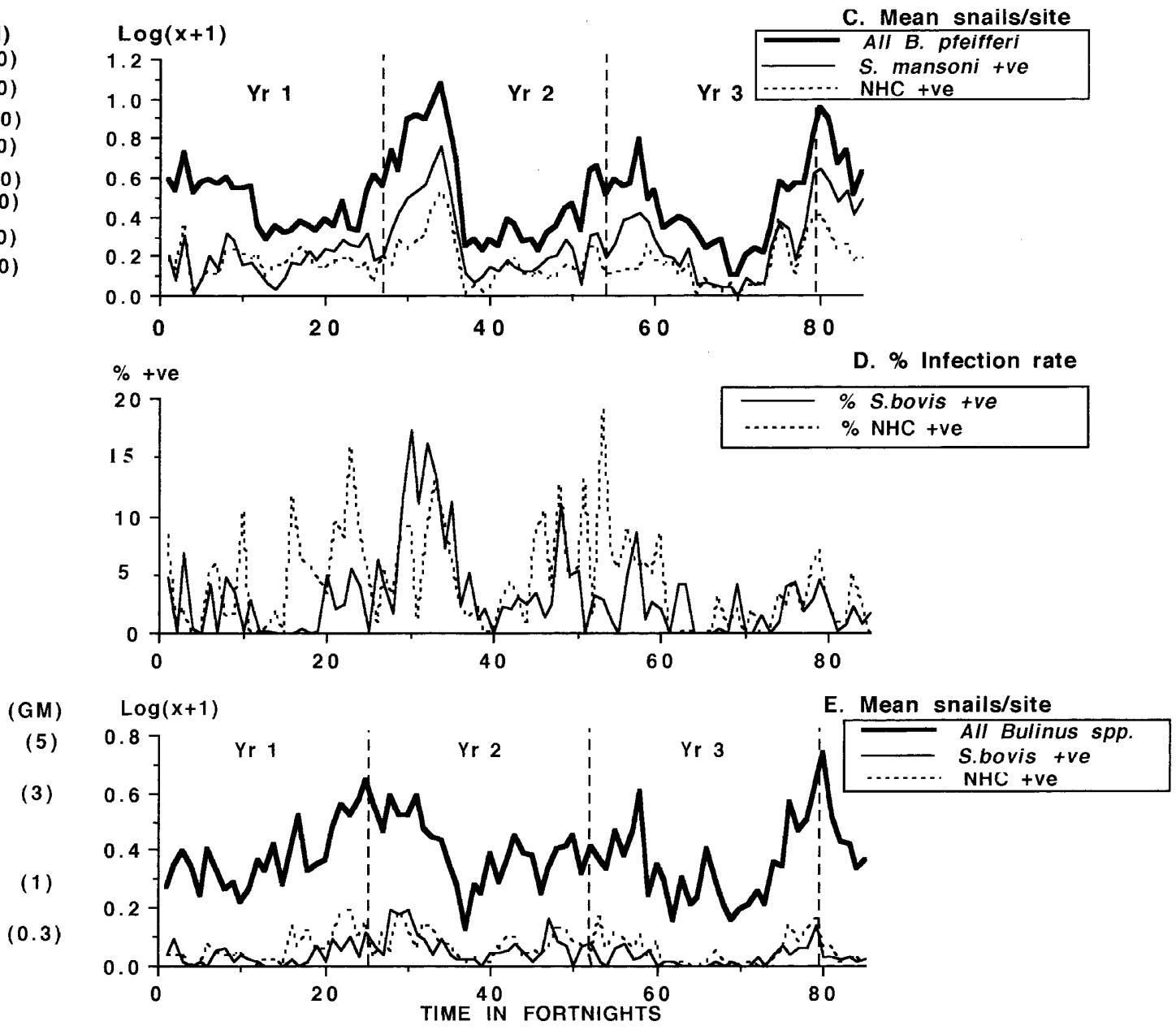

Fig. 1. Fortnightly means for 85 collections starting in May 1992 from all 24 original sites. A. water temperature in ${ }^{\circ} \mathrm{C}$ with standard deviations; B. arithmetic mean infection rates of B. pfeifferi with $S$. mansoni and other (non human) trematodes (NHC); C. geometric mean recoveries of B. pfeifferi: total and infected with S. mansoni or other trematodes; D. arithmetic mean infection rates of Bulinus spp. with S. bovis and NHC; and E. geometric mean recoveries of Bulinus spp.: total and infected with $S$. bovis or other trematodes.

S. mansoni-infected B. pfeifferi. S. mansoni infection rates mirrored total $B$. pfeifferi numbers (Fig. $1 \mathrm{~B})$ with peak rates in mid-summer dropping to a trough in mid-winter. The differences between months were significant $\left(\mathrm{F}_{11,72}=4.42, P<0.01\right)$. The same applied to habitats (data not shown) with 

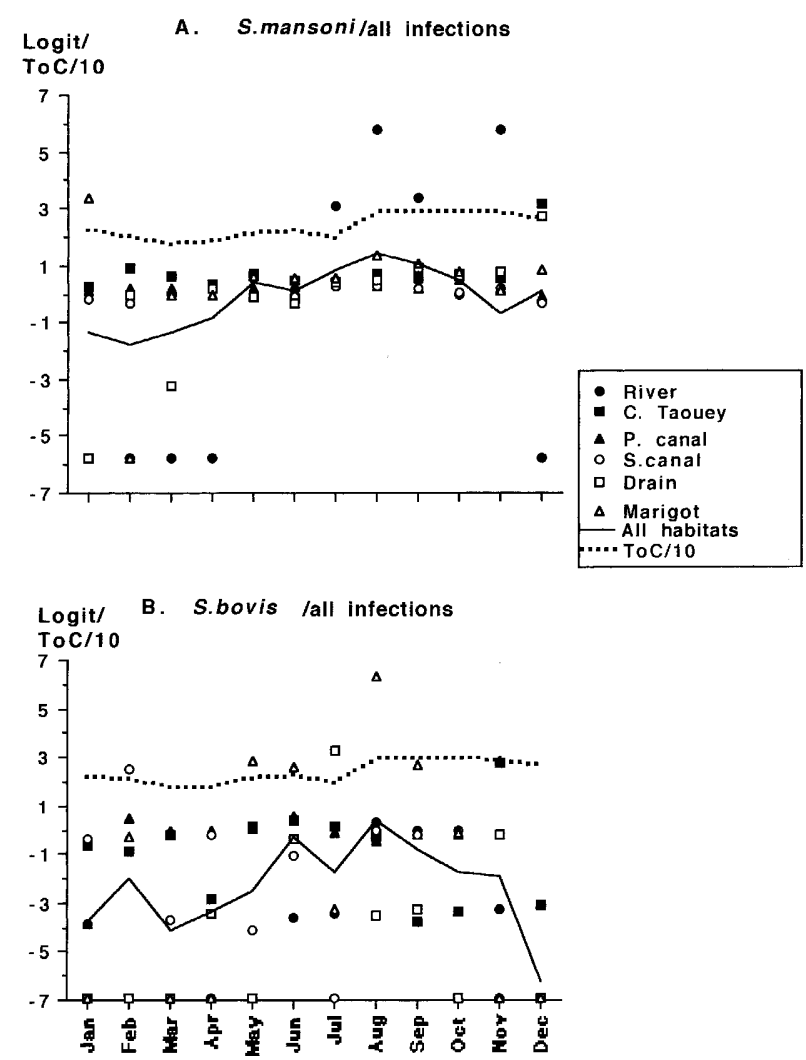

Fig. 2. Schistosome/(schistosome + other trematode) ratios from summary data plotted as logits by month and habitat. A. S. mansoni in B. pfeifferi and B. S. bovis in Bulinus spp. The solid line is the mean monthly ratio over all six habitats; the broken line is the mean, monthly water temperature in ${ }^{\circ} \mathrm{C} \times 10^{-1}$.

the highest rates in the primary canals, Canal Taouey and secondary canals $\left(\mathrm{F}_{5,72}=11.95, P<0.001\right)$. A significant interaction between these factors on $S$. mansoni infection rates was due to peak rates in the river occurring earlier than in other sites $\left(\mathrm{F}_{55,72}=\right.$ $2 \cdot 23, P<0 \cdot 01)$. Infection rates are sensitive to small sample size, even when transformed to angles, and the number of infected snails collected can be a more reliable indicator of transmission intensity.

There were significant differences in S. mansoniinfected snail numbers by habitat (Table 1(b)): primary canals and the drain yielded many more than the Canal Taouey, Marigot and secondary canal, with even less from the river $\left(\mathrm{F}_{5,72}=55 \cdot 4, P<\right.$ $0 \cdot 001)$. Variations over time were also significant $\left(\mathrm{F}_{11,72}=320 \cdot 8, P<0 \cdot 001\right)$. Infected snails were far more abundant in summer than in winter, with intermediate values in spring and autumn. The month $\times$ habitat interaction was significant $\left(\mathrm{F}_{55,72}=\right.$ 2.9, $P<0.001)$. Again, this was due to the earlier summer peak in the river from which snails all but disappeared in winter. S. mansoni infections were relatively scarce in the secondary canals, even in July and August, despite large snail populations in 1993 and 1994. B. pfeifferi occurred irregularly in the drain but had high infection rates if present in midsummer.
B. pfeifferi infected with other trematodes. $B$. pfeifferi non-human cercarial (NHC) infection rates were like those of S. mansoni, (Fig. 1 B), but were generally lower and the pattern during the year was a little different $\left(\mathrm{F}_{11,72}=4 \cdot 32, P<0 \cdot 01\right)$. Besides a late spring/early summer peak there was another in the autumn. There was a significant habitat effect (data not shown), with the highest rates in the primary canals, Canal Taouey and secondary canals $\left(\mathrm{F}_{5,72}=26 \cdot 07, P<0 \cdot 001\right)$.

Considering the actual numbers of NHC-infected $B$. pfeifferi, they were usually less common than $S$. mansoni-infections (Table 1(c)), especially in the summer months (Fig. 1 C). They varied significantly by month with more infected snails in early summer and autumn than in spring and winter $\left(\mathrm{F}_{11,72}=10 \cdot 1\right.$, $P<0.001)$. Their abundance also varied by habitat with significantly more from primary canal, secondary canals and the drain than from the other sites $\left(\mathrm{F}_{5,72}=66 \cdot 7, P<0.001\right)$.

Basic Bulinus spp. results

Total snails. The data for Bulinus spp. are summarised in Table $1(\mathrm{~g})$ and Fig. 1E. Cyclical fluctuations over time resembled $B$. pfeifferi, except that both the 'spring' build up and the mid-summer decline generally began rather earlier, especially in year 2, the hottest year. The normally lower abundance of Bulinus spp. compared with B. pfeifferi is clear from Figs $1 \mathrm{C}$ and $1 \mathrm{E}$, even at peak populations. Variation in snail numbers by month was significant $\left(\mathrm{F}_{11,72}=6 \cdot 17, P<0.001\right)$. So, too, was variation in abundance by habitat (Table $1(\mathrm{~g})$ ) with snails significantly more abundant in the river and Canal Taouey than in secondary canals and the Marigot $\left(\mathrm{F}_{5,72}=14.56 ; P<0.001\right)$. The month $\times$ habitat interaction (data not shown) was significant $\left(\mathrm{F}_{55,72}=3.23 ; P<0 \cdot 001\right)$. Spring population peaks were not discernible in the primary canals and Marigot, and autumn/winter peaks did not occur in the drain or secondary canals.

S. bovis infections of Bulinus spp. S. bovis infection rates varied during the year (Fig. $1 \mathrm{D})$, peaking in mid-summer but dropping to a trough in midwinter, and by habitat (Table $1(\mathrm{e})$ ). Infection rates were higher in summer than in winter months $\left(\mathrm{F}_{11,72}\right.$ $=4.32, P<0.01)$. Rates were highest in the primary canals, Canal Taouey and secondary canals $\left(\mathrm{F}_{5,72}=\right.$ 8.06, $P<0 \cdot 001)$.

Unlike S. mansoni, S. bovis infected snails were less abundant than other trematode infections in most habitats (Table 1 (c) and 1 (f)). The habitat pattern differed slightly compared with the infection rates, with higher recoveries from the Canal Taouey, primary canal and drain than from the Marigot and secondary canals $\left(\mathrm{F}_{5,72}=2 \cdot 6, P<0 \cdot 05\right)$. The numbers varied significantly by month with peak recoveries in July $\left(\mathrm{F}_{11,55}=3.95 ; P<0.001\right)$. 

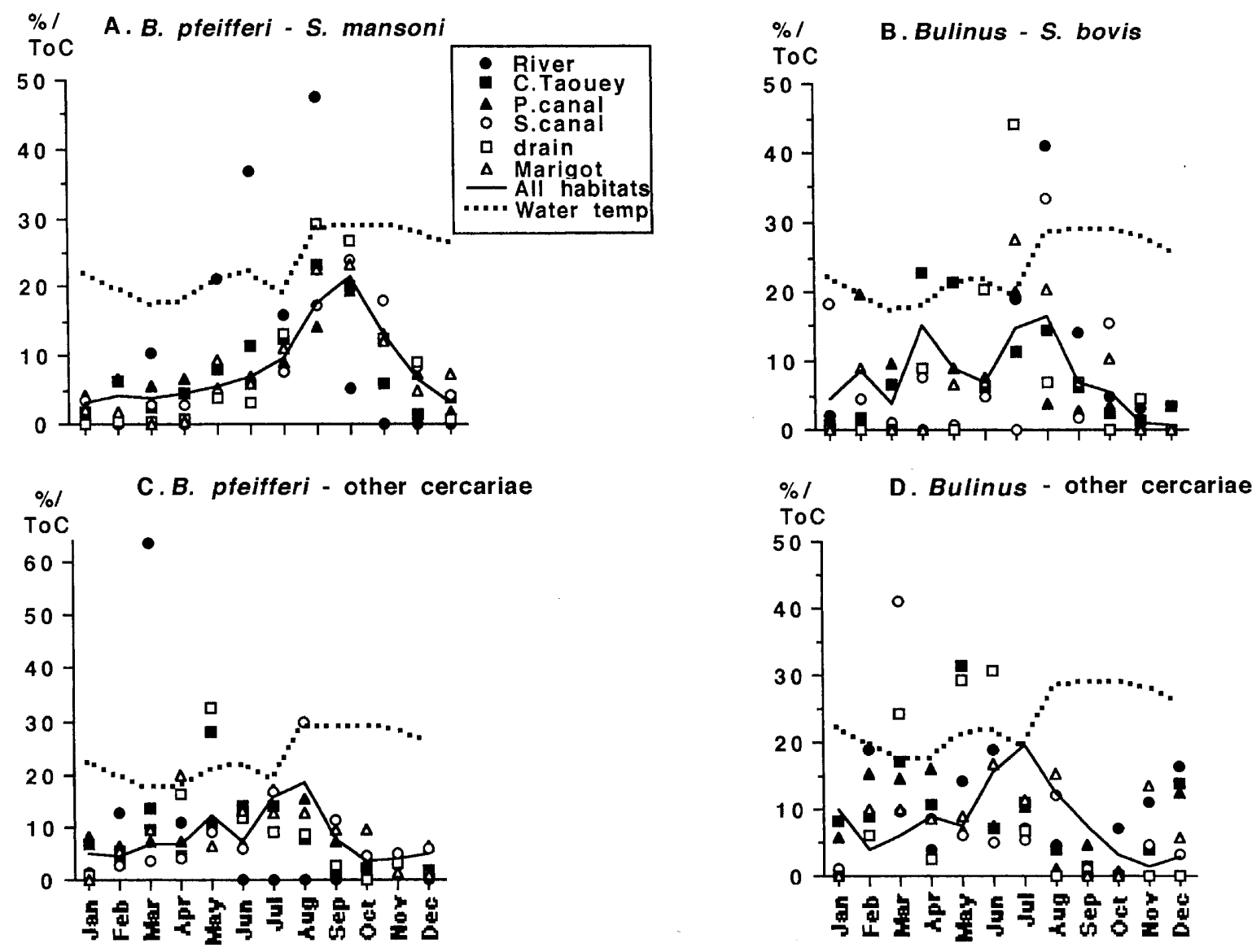

Fig. 3. Monthly transmission potential indices (MTPI) from summary data plotted as percentages by month and habitat. A. S. mansoni in B. pfeifferi; B. S. bovis in Bulinus spp. C. other trematodes (NHC) in B. pfeifferi and D. other trematodes in Bulinus spp. The solid line is the mean MTPI over all six habitats; the broken line is the mean, monthly water temperature in ${ }^{\circ} \mathrm{C}$.

Other trematode infections of Bulinus spp. Other trematode infection rates in Bulinus spp. varied during the year (Fig. 1D), with rather more pronounced peaks in late spring/early summer than for NHC infected $B$. pfeifferi, but with a similar midwinter trough $\left(\mathrm{F}_{11,72}=2 \cdot 54, P<0 \cdot 01\right)$. There were significant differences by habitat (data not shown), with the highest rates from the primary canals, Canal Taouey and secondary canals $\left(\mathrm{F}_{5,72}=7 \cdot 04, P<\right.$ $0 \cdot 001)$.

GM recoveries of snails infected with other trematodes ('Table 1 (f)) showed significant effects by habitat: infections were least abundant in the Marigot $\left(\mathrm{F}_{5,72}=3 \cdot 44, P<0 \cdot 05\right)$. They were significantly higher (Fig. $1 \mathrm{E}$ ) in mid-summer than in the winter, with intermediate values in the spring and autumn $\left(\mathrm{F}_{11.72}=4 \cdot 21, P<0 \cdot 001\right)$. The summer peaks occurred rather later than those of $S$. bovis.

\section{Relative infection rates}

S. mansoni and other trematode infections. $S$. mansoni infections accounted for over $60 \%$ of all $B$. pfeifferi trematode infections but the ratio $S$. mansoni/all infections varied during the year and by habitat (Fig. 2A, where equal proportions give a value of 0 on the logit scale). The difference between months was significant. S. mansoni predominated in the summer but was relatively scarcer in the winter $\left(\mathrm{F}_{11.72}=2 \cdot 7, P<0.01\right)$. The river rates were higher overall than those from other habitats $\left(\mathrm{F}_{5,72}=3 \cdot 9, P\right.$ $<0.01)$ and the significant month $\times$ habitat interaction $\left(\mathrm{F}_{55.72}=1.9, P<0.05\right)$ was due to the much greater difference between summer and winter recoveries from the river compared with other habitats.

S. bovis and other trematode infections. S. bovis accounted for less than $40 \%$ of all trematode infections detected in Bulinus spp. (ct. S. mansoni in $B$. pfeifferi). Overall $S$. bovis/all trematode ratios (Fig. 2B) showed an annual pattern similar to $S$. mansoni (Fig. 2A), peaking in early summer when they briefly exceeded zero (in the logit scale), and dropping in winter. There were significant differences by month $\left(\mathrm{F}_{11,72}=2 \cdot 8, P<0 \cdot 01\right)$ and by habitat $\left(\mathrm{F}_{5,72}=3 \cdot 6, P<0 \cdot 01\right)$. Ratios in the Canal Taouey and primary canals tended to be higher overall than those of the river and drain, with exceptionally high summer peaks in the Canal Taouey, the drain and the Marigot. 


\section{Monthly transmission potential indices (MTPI)}

For B. pfeifferi. The mean MTPI for S. mansoni (Fig. $3 \mathrm{~A}$ ) showed a summer peak and nearly $60 \%$ of the transmission occurred between May and September. The difference between months was significant $\left(\mathrm{F}_{11,72}=8 \cdot 51, P<0 \cdot 001\right)$. So, too, was the pattern for different habitats in the angular transformation $\left(\mathrm{F}_{5,72}=22.62 ; P<0.001\right)$ : the values were higher for the river than for other habitats. The month $\times$ habitat interaction was significant $\left(\mathrm{F}_{55,72}=\right.$ $2 \cdot 04 ; P<0.01)$. In the river and the drain, the proportion infected was high when snails were present but snails were often absent for long periods.

The MTPI for NHC in B. pfeifferi (Fig. 3C) showed a minor peak in May as well as the main summer peak in August. Over half the annual transmission occurred between May and August. The July and August indices were greater than those from October to February $\left(\mathrm{F}_{11,72}=3.53 ; P<0.001\right)$. The river MTPI were significantly less than from other habitats $\left(\mathrm{F}_{5,72}=15.40 ; P<0.001\right)$ in most months.

For Bulinus spp. The MTPI of S. bovis (Fig. $3 \mathrm{~B}$ ) had a minor peak in April as well as the main June/July summer transmission peak. These peaks contributed nearly two thirds of the annual transmission. The differences were significant by month: the April, July and August values were higher than those of other months $\left(\mathrm{F}_{11,72}=3.88 ; P<0.001\right)$. The habitat effect was also significant. The river and drain indices were less than those from the Canal Taouey and the primary canal $\left(\mathrm{F}_{5,72}=8 \cdot 12 ; P<\right.$ 0.001). There was a significant month $\times$ habitat interaction: spring peaks occurred in primary canals and Canal Taouey, and autumn peaks in the river and secondary canals $\left(\mathrm{F}_{55,72}=2 \cdot 14 ; P<0 \cdot 01\right)$.

For other trematodes in Bulinus spp., the MTPI peaked in July (Fig. 3D) with over $60 \%$ of the transmission in spring and early summer (June to August) when values were higher than those from September to April $\left(\mathrm{F}_{11,72}=6.91 ; P<0.001\right)$. The drain was significantly less important than other habitats $\left(\mathrm{F}_{5,72}=7 \cdot 81 ; P<0.001\right)$.

\section{DISCUSSION}

In this study, snails collected were not returned after examination for cercial infections. Such repeated depletion may eventually reduce the field snail populations in small, closed habitats. However, this was not a problem at Richard Toll where the habitats were large and open.

One-way analysis of variance on the full data agreed (with one exception) with two-way analyses of the summary data on the main factor (month and habitat) effects, giving confidence in the significance of interactions detected by the latter, where month was a surrogate for water temperatures because of the annual temperature cycle.

Belot et al. (1993) concluded that S. mansoni transmission occurred throughout the year at Richard Toll, but this does not preclude seasonality in its intensity which could be caused just by variations in $B$. pfeifferi abundance. This study shows such annual cycles in snail numbers and the intensity of both $S$. mansoni and $S$. bovis transmission.

The seasonal cycle in the numbers of $B$. pfeifferi and Bulinus spp. at Richard Toll resembled that in Egyptian irrigation schemes (Dazo, Hairston \& Dawood, 1966) : all snail populations grew rapidly in spring/early summer, dropped sharply in the heat of the summer and remained relatively low until the following spring. However, this pattern was modified by habitat, a phenomenon also noted more recently by Shaw et al. (1999). B. pfeifferi was more abundant in smaller, man-made habitats (primary and secondary canals) but peaked later in the larger, natural (river and Marigot) and man-made (Canal Taouey) habitats where wave action and/or substantial flows restricted snails to sheltered microhabitats among vegetation. Bulinus spp. preferred larger, natural habitats where their populations peaked earlier than $B$. pfeifferi with, sometimes, a secondary, autumn peak.

The effects of temperature on snail survival and reproduction are well known (Appleton, 1977; Dazo et al. 1966; Shiff, 1964; Sturrock, 1966; Sturrock \& Sturrock, 1972) as, too, are its effects on the rate of development of intramolluscan stages of schistosomes (Foster, 1964; Pflüger, 1981). Water temperature (month), habitat type and their interaction also affects the behaviour of the definitive hosts of the schistosomes, influencing the type, degree and frequency of contact with and contamination of transmission sites by humans as well as animals transmitting non-human schistosomes and other snail-borne trematodes.

Fish, amphibians, reptiles, birds and rodents were seen at most water bodies in and around Richard Toll. Cattle, goats and horses had unrestricted access to the river, Marigot and Canal Taouey where $S$. bovis infections were most common, but were discouraged (not always successfully) from canals and drains to prevent damage to their earthen banks. Almost every accessible water body was also utilised by people throughout the year, although casual observation suggested more prolonged contact in the hotter, summer months, especially among children.

For most of the year, S. mansoni was more common than other trematodes in B. pfeifferi, with a single transmission peak between May and August depending on the habitat. Nearly $80 \%$ of all $S$. mansoni-infected snails were found in this period; mostly from the Canal Taouey and the primary canals with only a few from the river. In contrast, $S$. 


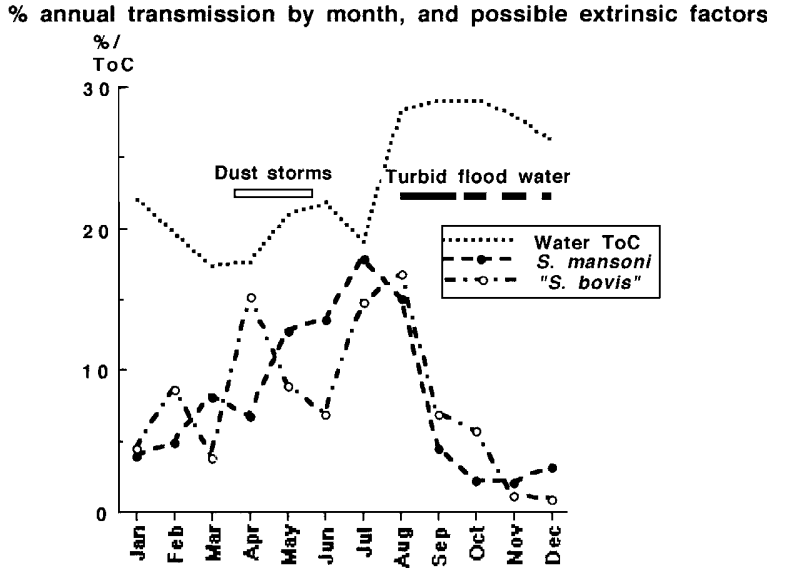

Fig. 4. Monthly transmission potential indices (MTPI) plotted as percentages for S. mansoni in B. pfeifferi (bold broken line) and $S$. bovis in Bulinus spp. (broken line), together with other seasonal factors that may affect transmission. The dotted line is mean monthly water temperature in ${ }^{\circ} \mathrm{C}$; the solid bars indicate the periods when flood water is passing and the open bar shows the period when dust storms occur.

bovis, less common than other trematodes in Bulinus spp., except in the Marigot and secondary canals, was most abundant in the primary canals, the Canal Taouey and river. Its seasonality resembled that of $S$. mansoni but peak summer transmission occurred slightly earlier, with minor autumn peaks in some habitats.

The local strain of $S$. mansoni is very compatible with local $B$. pfeifferi and has a normal midday peak of cercarial shedding (Tchuem Tchuente et al. 1999). It is also compatible with local rodents (Sène et al. 1996). However, naturally-infected wild rodents were found only from September to November by Sène (1994) and Sène et al. (1996). Presumably these infections were acquired two or three months earlier during the late spring/summer transmission peak. The lack of natural infections in rodents in spring and early summer suggests little winter transmission, even though infected snails were sometimes found in small numbers during the cooler winter months. As infections were detected by forced shedding in the laboratory, cercariae may not have been shed in the cooler field sites. Low temperatures would also have slowed the development of infections and hence the number of cercariae produced. Elsewhere in the region, both Ernould et al. (1999a) and Shaw et al. (1999) reported seasonality in the transmission of $S$. mansoni but De Clercq et al. (1999) observed it throughout the year round the Lac de Guiers. Cercariometry (Théron, 1986) or animal exposures (Prentice \& Ouma, 1984) might help to resolve these contradictions.

The relative abundance of schistosomes and other trematodes is interesting. In addition to schistosome cercariae, B. pfeifferi and Bulinus spp. each shed at least two other trematodes. It was not possible to identify them but numerous potential definitive hosts (see above) had access to most sites. Bulinus spp. were historically widespread along the Senegal River and would already have acquired a trematode fauna, including schistosomes (which remain in the minority) before the recent hydrological changes. In contrast, the widespread abundance of $B$. pfeifferi has developed only recently. S. mansoni, introduced by man, is the commonest trematode: perhaps the situation will change as other trematodes such as amphistomes and paramphistomes start to utilise this newly available host.

The dynamics of snail populations and parasite transmission are affected by many factors other than water temperature. A long-term shift in water conditions from acid to alkaline since completion of the dams favours both processes (Southgate, 1997). Some other seasonal factors are indicated in Fig. 4. Seasonal dust and sand storms from the Sahara in the spring months choke aquatic vegetation, smothering its growth and the development of snail eggs. The same effect could be due to silt-laden flood water, as in Sudanese irrigation schemes (Babiker et al. 1985). Although the Manantali Dam has reduced the natural seasonal flood (Diop et al. 1994), warm and silt-laden water from downstream rainfall runoff still reaches Richard Toll in mid-summer coinciding with the declining snail populations from mid-summer onwards. Atypical irrigation routines when the sugar factory is closed in July and August may affect snail populations adversely. So, too, will dredging and weed clearance to maintain water flows in canals and drains. Periodic release of waste products from the sugar factory into nearby secondary canals temporarily eliminated snail populations, but only locally in sites remote from human contact.

Long-term ecological changes consequent on the water resource developments are still in progress in the Senegal River Valley: some may be permanent, others transient. At present, the changes have favoured the spread and growth of $B$. pfeifferi populations so that $S$. mansoni is the main problem at Richard Toll. During these studies, there was no evidence of increased haematuria in the local residents, nor were significant numbers of $S$. haematobium eggs found, suggesting that urinary schistosomiasis is not a threat at Richard Toll. $B$. senegalensis, known to transmit the local strain of $S$. haematobium (Picquet et al. 1996), occurred sporadically but does not seem to thrive in the newly created habitats. Nor does the local strain of $B$. globosus. At Richard Toll, the commonest bulinid snail, B. truncatus, seems better adapted to the new habitats, though less so than $B$. pfeifferi. It poses no immediate threat (Southgate, 1997), unless a compatible strain of the parasite is imported from elsewhere in West Africa (Vera, 1992). B. truncatus is a greater threat to domestic animals as putative $S$. 
bovis infections were quite common. The greatest danger is that $B$. globosus could eventually invade canals at Richard Toll, allowing the introduction of a local, compatible strain of $S$. haematobium from existing nearby foci in the Senegal River Delta (Verlé et al. 1994; Ernould et al. 1999b).

Extrapolation of the findings at Richard Toll to other areas of the Senegal River Basin requires some caution. Before 1980, there were essentially only two types of habitat available for freshwater snails in the lower Senegal River basin: the Senegal River and its tributaries or temporary, rain-fed pools on elevated laterite soils away from the river. Both are subject to the seasonal effects already discussed. The pools represent more extreme conditions and snails colonising them require considerable powers of aestivation to survive for many months when they dry out. B. pfeifferi is only moderately tolerant of droughts and was originally restricted to a few, stable sites around the Lac de Guiers in numbers too small to support transmission or to allow its introduction by infected immigrants. Bulinus spp., especially $B$. senegalensis, were better adapted to these conditions and were widely enough distributed to support low level transmission of schistosomes and other trematodes. Extensive development of rice irrigation in the region has been followed by local upsurges in S. haematobium transmission (Verlé et al. 1994; Shaw et al. 1999; Picquet et al. 1998).

Chaine \& Malek (1983) predicted that any human schistosome problem that the proposed dams might create would involve $S$. haematobium. This prediction seemed reasonable in the light of experience in Ghana after the construction of the Volta Dam (Paperna, 1969; Klumpp, 1982) but overlooked the new types of habitats that would be created along the Senegal River. The development of sugar irrigation at Richard Toll provided a foretaste of the effects of the dams on the Senegal River.

At Richard Toll, natural habitats around the Lac de Guiers were stabilised and protected from sea water intrusion, allowing $B$. pfeifferi populations to proliferate and invade the irrigation scheme as water was pumped via the Canal Taouey into the canal system. B. pfeifferi populations exploded in the relatively stable conditions within the canal system. A parallel invasion of infected people detonated the subsequent $S$. mansoni epidemic because conditions were ideal for transmission. There was no $S$. haematobium epidemic as in Ghana because $B$. truncatus, the only bulinid snail that thrived in the newly created habitats, is incompatible with the $S$. haematobium strain at Richard Toll (Picquet et al. 1996).

What happens next outside the sugar irrigation scheme depends on the types of habitat created there by construction of the dams. From this study, the spread of S. mansoni seemed inevitable. The Senegal River and its tributaries had been stabilised into a freshwater lake stretching back from the Diama Dam to Richard Toll and beyond. Numerous canals have been constructed to serve new, extensive rice irrigation schemes. Whether or not rice fields form important transmission sites (Mather, 1984), they provide suitable habitats for $B$. senegalensis (Vercruysse et al. 1985) with a risk of spreading $S$. haematobium transmission, and their canals could provide suitable habitats for $B$. pfeifferi favouring the spread of $S$. mansoni. This is no longer theoretical speculation. B. pfeifferi colonies are now established in Senegal in the river and canals well downstream from Richard Toll where $S$. mansoni is now established (Talla et al. 1992; Ernould \& Ba, 1994; Gryseels et al. 1994; Picquet et al. 1996; Ernould et al. 1999a). In Mauritania, both B. pfeifferi and $S$. mansoni are established opposite Richard Toll up to $50 \mathrm{~km}$ from the Senegal River (Diop et al. 1994). Ominously, S. haematobium transmission through $B$. globosus has now been found in canals serving a rice irrigation schemes between Richard Toll and the coast (Verlé et al. 1994) and in other habitats (Ernould et al. 1999b). Perhaps Chaine \& Malek's original prediction may still come true.

So far, attempts to contain the spread of schistosomiasis in and around Richard Toll have relied predominantly on treatment with praziquantel (Southgate, 1997). The findings of this study suggest that population-based chemotherapy for S. mansoni should avoid the transmission season between May and September because of the high risk of rapid reinfection. Snail numbers and infection rates are minimal between November and February when human infections acquired in the previous transmission season will be easy to diagnose and susceptible to drugs. This view is supported for $S$. haematobium on the Lac de Guiers, where transmission is light and highly seasonal, and De Clercq et al. (1999) reported effective treatments in both January 1996 and March 1997. The result was less satisfactory for $S$. mansoni in the face of much heavier and more prolonged transmission. Since human $S$. mansoni infections were much more intense than those of $S$. haematobium, infections in April 1996 probably represent worms surviving treatment: two or more treatments would be needed to dislodge them before the main transmission season later in the year (Picquet et al. 1998). In areas where both human schistosomes occur, ecological differences in the (different) habitats of their respective snail hosts may affect the timing and intensity of transmission seasons. This may be an alternative explanation to inter-specific competition between adult worms in the definitive host for the differential effects of praziquantel treatment on the two species (Ernould et al. 1999a).

It is unlikely that chemotherapy alone will ever eradicate transmission. Safe, well-maintained water supplies and improved sanitation, reinforced by 
education, would reduce transmission of $S$. mansoni and many other diseases besides, but their provision needs considerable long-term investment and commitment. Progress towards a vaccine is being made but it is likely to be many years before one will be available for widespread use. In the meantime, chemotherapy could be supplemented with well timed mollusciciding of canals on sugar and rice irrigation schemes to interrupt transmission at an acceptable cost. The use of molluscicides elsewhere is precluded by its prohibitive expense and unacceptable fish kills.

\section{ACKNOWLEDGEMENTS}

This work was performed as part of the ESPOIR programme for research and control of schistosomiasis in the Senegal River Basin which received financial support from the Commission of the European Communities Research Programme 'Life Sciences and Technologies for Developing Countries and the Region Nord Pas de Calais. We wish to acknowledge the diligent work of our field teams, in particular M. Johnson and O. Sow, and the Compagnie Sucrière Sénégalais for their cooperation in the field work.

\section{REFERENCES}

abDel-Wahab, M. F. (1982). Schistosomiasis in Egypt. pp. 62-65. Florida, Boca Raton, CRC Press.

APPLETON, C. C. (1977). The influence of temperature on the life-cycle and distribution of Biomphalaria pfeifferi (Krauss, 1948) in south-eastern Africa. International Fournal for Parasitology 7, 335-345.

BABIKER, A., FENWICK, A., DAFAlla, A. A. \& AMin, M. A. (1985). Focality and seasonality of Schistosoma mansoni transmission in the Gezira Irrigated Area, Sudan. Fournal of Tropical Medicine and Hygiene $\mathbf{8 8}$, 65-73.

BELOT, J., GEERTs, S. \& Diouf, M. (1993). Observations on the population dynamics of snail hosts for schistosomiasis in the Delta of the Senegal River. Fournal of Molluscan Studies 59, 7-13.

BRown, D. s. (1994). Freshwater Snails of Africa and their Medical Importance. 2nd Edition. p. 228, London. Taylor \& Francis.

CHAINE, J. P. \& MALEK, E. A. (1983). Urinary schistosomiasis in the Sahelian region of the Senegal River Basin. Tropical and Geographical Medicine 35, 249-256.

DAzo, B. C., HAIRSTON, N. G. \& DAWood, I. K. (1966). The ecology of Bulinus truncatus and Biomphalaria alexandrina and its implication for the control of bilharzia in the Egypt-49 control area. Bulletin of the World Health Organization 35, 339-356.

DE ClercQ, D., Vercruysse, J., PICQuet, M., ShaW, D. J., DIOP, M., LY, A. \& GRYSEELS, B. (1999). The epidemiology of a recent focus of mixed Schistosoma haematobium and S. mansoni infections around the Lac de Guiers in the Senegal River Basin. Tropical Medicine and International Health 4, 544-550.

DEME, I. (1993). Epidémiologie des bilharzioses humaines et animales dans le Delta du bassin du Fleuve Sénégal: étude malacologique. MSc thesis, Prince Leopold Institute, Antwerp, Belgium.
DIAW, O. T., VASSILIDES, G., SEYE, M. \& SARR, Y. (1990). Proliférations de mollusques et incidence sur les trématodoses dans la Region du delta et du lac de Guiers après la construction du barrage de Diama sur le fleuve Sénégal. Revue de l'élevage et de Médecine Véterinaire de Pays Tropicaux 43, 499-502.

DIAW, O. T., VASSILIDES, G., SEYE, M. \& SARR, Y. (1991). Epidémiologie de la bilharziose intestinale à Schistosoma mansoni à Richard Toll (Delta du fleuve Sénégal): étude malacologique. Bulletin de la Société de Pathologie Exotique 84, 174-183.

DIOP, M., JOBIN, W. R., ADREIN, N. G., ARFAa, F., AUBEL, J., BERTLOIMINOR, S., KLUMPP, R. \& ROSENMAAL, J. (1994). Senegal River Basin Health Master Plan Study. 163 pp., Washington, WASH Field Report 453, USAID. ERNOULD, J.-C. \& BA, K. (1994). Cartographies du bas delta du fleuve Sénégal: resultats préliminaire (avril 1994). L'eau et la santé dans les contextes du dévelopment. ORSTOM-St Louis. ORSTOM/ES/DK/72.94.

ERNOULD, J. C., BA, K. \& SELLIN, B. (1999a). The increase of intestinal schistosomiasis after praziquantel treatment in a Schistosoma haematobium and $S$. mansoni mixed focus. Acta Tropica 73, 143-152.

ERNOULD, J. C., BA, K. \& SEllin, B. (1999b). The impact of the local water-development programme on the abundance of the intermediate hosts of schistosomiasis in three villages of the Senegal River Delta. Annals of Tropical Medicine and Parasitology 93, 135-145.

FALLON, P. G., STURROCK, R. F., CAPRON, A., NIANG, M. \& DOENHOFF, M. J. (1995). Diminished susceptibility to praziquantel in a Senegal isolate of Schistosoma mansoni. American Fournal of Tropical Medicine and Hygiene 53, 61-62.

FOSTER, R. (1964). The effect of temperature on the development of Schistosoma mansoni Sambon 1907 in the intermediate host. Fournal of Tropical Medicine and Hygiene 67, 289-292.

FUlford, A. J. C., BUtTerworth, A. E., DUNNe, D. W., STURROCK, R. F. \& OUMA, J. H. (1996). Some mathematical issues in assessing the evidence for acquired immunity to schistosomiasis. In Models for Infectious Diseases. Their Structure and Relation to Data (ed. Isham, V. \& Medley, G.), pp. 139-159. Cambridge, Cambridge University Press.

GRYSEels, B., STELMa, F. F., TALla, I., VAN DAM, G. J., POllman, K., SOW, S., DiAW, M., STURrock, R. F., DOEHRING-SCHWERDTFEGER, E., DECAM, C., NIANG, M. \& DEELDER, A. M. (1994). Epidemiology, immunology and chemotherapy of Schistosoma mansoni infections in a recently exposed community in Senegal. Tropical and Geographic Medicine 46, 209-219.

HANDSCHUMaCher, P., DORSAINVILle, R., DiaW, O.-T., HEBRARD, G., NIANG, M. \& HERVE, J.-P. (1992).

Constraints climatiques et amenagements hydroliques à propos de l'epidémie de bilharziose intestinale de Richard-Toll (Sénégal) ou la modification des risques sanitaire en milieu sahelian. In Risques Pathalogiques, Rythmes et Paroxysmes Climatiques (ed. Besancenot, J. P.), pp. 287-295. Paris, John Libbey Eurotext.

HANDSChUMaCher, P., TALla, I., HERVÉ, J.-P., DUPLANTIER, J. M., SENE, M., DIAW, O.-T. \& HEBRARD, G. (1994). Petit Atlas Informatise de Richard Toll. 
Environment Urbain et Bilharziose Intestinal. Dakar, ORSTOM.

JOBIN, W. R., NEGRON-APONTE, H. \& MICHELSON, E. H. (1976). Schistosomiasis in the Gorgol Valley of Mauritania. American Fournal of Tropical Medicine and Hygiene 25, 587-594.

KLUMPP, R. K. (1982). A study on the transmission of Schistosoma haematobium in Volta Lake, Ghana. PhD thesis. London University, pp. 307-315.

MALEK, E. A. \& CHAine, J. P. (1989). Effects of the developments in the Senegal River Basin on the prevalence and spread of schistosomiasis. In Demography and Vector-borne Diseases (ed. Service, M. W.), pp. 181-192, Boca Raton, Florida, CRC Press.

MATHER, T. H. (1984). Environmental management for vector control in rice fields. Food and Agriculture Organization Drainage paper 41. Rome.

MONJOUR, L., NIEL, G., MOGahed, A., SIDATT, M. M. \& GENTILINI, M. (1981). Geographic distribution of bilharziasis in the Senegal River Valley (seroepidemiologic evaluation - 1973). Annales de la Société Bélgiques de Médecine Tropicale 61, 453-460.

OLIVIER, L. \& SCHNEIDERMANN, M. (1956). A method for estimating the density of aquatic snail populations. Experimental Parasitology 5, 109-117.

OUMA, J. H., STURROCK, R. F., KLUMPP, R. K. \& KARIUKI, H. C. (1989). A comparative evaluation of snail sampling and cercariometry to detect Schistosoma mansoni transmission in a large-scale, longitudinal field study in Machakos, Kenya. Parasitology 94, 349-355.

PAPERNA, I. (1969). Study of an outbreak of schistosomiasis in the newly formed Volta Lake in Ghana. Zeitschrift für Tropenmedizin und Parasitologie 21, 339-353.

PFLÜGER, W. (1981). Experimental epidemiology of schistosomiasis. II. Prepatency of Schistosoma mansoni in Biomphalaria glabrata at diurnally fluctuating temperatures. Zeitschrift für Parasitenkunde 66, 221-229.

PICQUeT, M., ERNOUlD, J. C., VERCRUYSSE, J., SOUthGate, V. R., MBAYE, A., SAMBOU, B., NIANG, M. \& ROLLINSON, D. (1996). The epidemiology of human schistosomiasis in the Senegal River Basin. Transactions of the Royal Society of Tropical Medicine and Hygiene 90, 340-346.

PiCQUeT, M., VERCRUYSSE, J., SHAW, D. J., DiOP, M. \& LY, A. (1998). Efficacy of praziquantel against Schistosoma mansoni in northern Senegal. Transactions of the Royal Society of Tropical Medicine and Hygiene 92, 90-93.

PRENTICE, M. A. \& OUMA, J. H. (1984). Field comparison of mouse immersion and cercariometry for assessing the transmission potential of water containing cercariae of Schistosoma mansoni. Annals of Tropical Medicine and Parasitology 78, 169-174.

ROLlinson, D., SOUTHGATE, V. R., VERCRUYSSE, J. \& MOORE, P. J. (1990). Observations on natural and experimental interactions between Schistosoma bovis and S. curassoni from West Africa. Acta Tropica 47, 101-114.

SÈNE, M. (1994). Étude de la schistosomiasis intestinale chez les rongeurs suavages à Richard Toll (Sénégal) : suivi de l'infestation naturelle et transmission expérimentale. Thèse de $3^{\circ}$ cycle, Université Cheikh Anta Diop, Dakar. 87 pp.

SÈNE, M., DUPLANTIER, J. M., MARChand, B. \& HERVÉ, J. P. (1996). Susceptibility of rodents to infection with Schistosoma mansoni in Richard Toll (Senegal). Parasite 3, 321-326.

ShaW, D. J., Vercruysse, J., PicQuet, M., SAMbou, B. \& LY, A. (1999). The effect of different treatment regimens on the epidemiology of seasonally transmitted Schistosoma haematobium infections in four villages in the Senegal River Basin, Senegal. Transactions of the Royal Society of Tropical Medicine and Hygiene 93, 142-150.

ShIFF, C. J. (1964). Studies on Bulinus (Physopsis) globosus in Rhodesia, I. The influence of temperature on the intrinsic rate of natural increase. Annals of Tropical Medicine and Parasitology 58, 94-105.

southgate, v. R. (1997). Schistosomiasis in the Senegal River Basin: before and after the construction of the dams at Diama, Senegal, and Manantali, Mali, and future prospects. Fournal of Helminthology 71, $125-132$.

STElma, F. F., TAlla, I., SOW, S., KONGS, A., NiANG, M., POLlMAN, K., DEELDER, A. M. \& GRYSEELS, B. (1995). Efficacy and side effects of praziquantel in an epidemic focus of Schistosoma mansoni. American Fournal of Tropical Medicine and Hygiene 53, 167-170. STURROCK, R. F. (1996). The influence of temperature on the biology of Biomphalaria pfeifferi (Krauss), an intermediate host of Schistosoma mansoni. Annals of Tropical Medicine and Parasitology 60, 100-105.

STURROCK, R. F., KLUMPP, R. K., OUMA, J. O., BUtTERWORTH, A. E., FULFORD, A. E., KARIUKi, H. C., THIONGO, F. W. \& KOECH, D. (1994). Observations on the effects of different chemotherapy strategies on the transmission of Schistosoma mansoni in Machakos District, Kenya, measured by long-term snail sampling and cercariometry. Parasitology 109, 443-453.

STURRock, R. F. \& STURROCK, B. M. (1972). The influence of temperature on the biology of Biomphalaria glabrata (Say), intermediate host of Schistosoma mansoni on St Lucia, West Indies. Annals of Tropical Medicine and Parasitology 66, 385-398.

TAlla, I., KONGS, A., Verlé, P., BElot, J., SARR, S. \& COLl, A. M. (1990). Outbreak of intestinal schistosomiasis in the Senegal River Basin. Annales de la Société Belgiques de Médecine Tropicale 70, 173-180.

TAlla, I., KONGS, A. \& Verlé, P. (1992). Preliminary study of the prevalence of human schistosomiasis in Richard Toll (Senegal River Basin). Transactions of the Royal Society of Tropical Medicine and Hygiene 86, 182.

TCHUEM TCHUENTE, L. A., SOUthgate, v. R., ThÉRON, A., Jourdane, J., Ly, A. \& GrYseELs, B. (1999). The compatability of Schistosoma mansoni and Biomphalaria pfeifferi in northern Senegal. Parasitology 118, 595-603.

THÉRon, A. (1986). Cercariometry and the epidemiology of schistosomiasis. Parasitology Today 2, 61-63.

VERA, C. (1992). Contribution à l'étude de la variabilité génètique des schistosomes et leurs hôtes intermediaries: polymorphisme de la compatabilité entre diverse populations de Schistosoma haematobium, 
$S$. bovis et S. curassoni et les bulins hôtes potentiels en Afrique de l'Ouest. PhD thesis, Université Montpellier. ORSTOM, Paris. 303 pp.

VERCRUYSSE, J., SOUthGate, V. R. \& ROLLINSON, D. (1985).

The epidemiology of human and animal

schistosomiasis in the Senegal River Basin. Acta Tropica 42, 249-259.

VERCRUYSSE, J., SOUthGATE, V. R., ROLlinson, D., DE ClerCQ, D., SACKO, M., DE BONT, J. \& MUNGOMba, L. M.
(1994). Studies on the transmission and schistosome interactions in Senegal, Mali and Zambia. Tropical and Geographic Medicine 46, 220-226.

verlé, P., Stelma, F., DÈsreumaux, P., Dieng, A., DiaW, O., Niang, M., SOW, S., TALla, I., STURROCK, R. F., GRYSEELS, B. \& CAPRON, A. (1994). Preliminary study of urinary schistosomiasis in the delta of the Senegal River Basin, Senegal. Transactions of the Royal Society of Tropical Medicine and Hygiene 88, 401-405. 